NOVELAR CONTRA LA MISERIA.

\title{
CORRUPCIÓN Y LITERATURA DURANTE LA RESTAURACIÓN BORBÓNICA (1875-1923)
}

\author{
To fictionalise against misery. \\ Corruption and literature during the Spanish Bourbon Restoration (1875-1923)
}

\author{
Jaume Muñoz Jofre \\ Universitat Autònoma de Barcelona \\ jaumemzjofre@gmail.com
}

Cómo citar este artículo/Citation:

Jaume MUÑOZ JOFRE (2018), "Novelar contra la miseria. Corrupción y literatura durante la Restauración borbónica (1875-1923)", Hispania Nova, 16, págs. 558-589. DOI: https://doi.org/10.20318/hn.2018.4048
Copyright: (C) HISPANIA NOVA es una revista debidamente registrada, con ISSN 1138-7319 y Depósito Legal M 9472-1998. Los textos publicados en esta revista están -si no se indica lo contrario- bajo una licencia Reconocimiento-Sin obras derivadas 3.0 España de Creative Commons. Puede copiarlos, distribuirlos y comunicarlos públicamente siempre que cite su autor y la revista y la institución que los publica y no haga con ellos obras derivadas. La licencia completa se puede consultar en: http://creativecommons.org/licenses/by-nd/3.0/es/deed.es

\begin{abstract}
Resumen: Los distintos tipos de corrupción en los que se basaba el sistema de la Restauración borbónica en España (1875-1923) no eran, en absoluto, desconocidos por sus habitantes. La corrupción electoral era la primera pieza de un complejo engranaje que afectaba a todos los niveles de la Administración y la sociedad españolas de la época: en un país todavía mayoritariamente rural, el atraso sociológico y la desmovilización política permitían el tráfico de favores desde las posiciones de poder. Durante el periodo, distintos intelectuales retrataron el sistema en novelas con vocación (y éxito) comercial, pero también escritas con voluntad de concienciación política del lector. Dentro de sus tramas se describen el ambiente necesario para que se pueda ejercer la dominación social que caracterizaba el sistema, así como las malas prácticas de sus gobernantes, ya fuera en el campo como en las grandes ciudades. Este artículo analiza cinco de ellas, reivindicando el gran valor de la literatura como fuente histórica.
\end{abstract}

Palabras clave: corrupción, literatura, Restauración borbónica, Santiago Rusiñol, Felipe Trigo, Carles Bosch de la Trinxeria, José López Pinillos.
Abstract: The Spanish Bourbon Restoration's system (18751923) was completely based on corruption. A heterogeneous but restricted oligarchy ruled the country thanks to the remarkably miserable conditions that the vast majority of the Spanish society had to live in. Fraudulent elections were one of the most obvious kinds of corruption developed then, when the whole functioning of the State was lubricated by the favours trade. This underdeveloped society was portrayed by some Spanish intellectuals describing in their novels this tainted atmosphere and the necessary conditions to maintain it. Written with a political intention but with a commercial finality, these works are excellent historical sources. This article analyses five of these novels, which are excellent pictures of a crippled society, either in the countryside or the city.

Keywords: corruption, literature, Spanish Bourbon Restoration, Santiago Rusiñol, Felipe Trigo, Carles Bosch de la Trinxeria, José López Pinillos. 


\section{Introducción}

A finales de diciembre de 1874, el General Arsenio Martínez Campos ponía fin mediante un pronunciamiento militar en Sagunto al Sexenio Democrático (1868-1874), periodo de espíritu democratizador y de gran agitación política. Gracias a este golpe nacía un nuevo sistema, la Restauración borbónica, que, en contraste, y como ha acertado a observar Àngel Duarte, fue una "auténtica reacción conservadora encaminada a asegurar la participación exclusiva de las minorías propietarias en la vida política" ${ }^{1}$. Diseñado por Antonio Cánovas del Castillo, el nuevo sistema requería, en consecuencia, de una gran desmovilización política por parte del pueblo español. Y, aunque pueda parecer paradoxal al haber nacido la Restauración gracias a un golpe militar, uno de los principales cambios que se impulsaría sería el de erradicar una de las principales costumbres políticas del siglo XIX: se buscó apartar a los militares de la centralidad política y, más concretamente, de la capacidad de cambiar gobiernos a base de pronunciamientos. Para hacerlo se instauraría a partir de entonces un turno pacífico en el que los cambios gubernamentales se gestarían desde el poder y se corroborarían mediante elecciones a Cortes absolutamente fraudulentas, diseñadas desde el propio Gobierno (con especial protagonismo del ministerio de la Gobernación) $)^{2}$.

La corrupción electoral era, pues, la base desde la que erigía un sistema corrupto por definición, cuyos engranajes funcionaban gracias a lo que José Varela Ortega teorizó como el poder de la influencia -es decir, la capacidad de satisfacer a las clientelas políticas que un cacique (local, provincial, regional) consiguiese tener ${ }^{3}$. El atraso sociológico y económico español permitió que este sistema funcionara durante

\footnotetext{
${ }^{1}$ Àngel DUARTE: La España de la Restauración (1875-1923). (Barcelona: Hipòtesi, 1997), p. 9.

${ }^{2}$ La fabricación de mayorías parlamentarias no era ninguna novedad en la historia española, pero Cánovas innovó en conseguir que estos cambios se produjeran pacíficamente.

${ }^{3}$ Ver José VARELA ORTEGA (director): El poder de la influencia. Geografía del caciquismo en España (1875-1923). (Madrid: Centro de Estudios Políticos y Constitucionales - Marcial Pons, 2001)
} 
casi cincuenta años, ya fuera con sufragio censitario o universal (masculino) ${ }^{4}$. Y es que si el sistema de la Restauración entró en decadencia no fue por la grosería de su corrupción, sino por la modernización social y económica que paulatinamente se fue produciendo con el paso de las décadas -acompañado, todo ello, de muestras incontrovertibles de la decadencia española en el plano internacional, desde el Desastre de 1898 hasta el de Annual (1921).

Con el paso de las décadas, el sistema canovista acabó siendo insostenible porque los tiempos cambiaron, pero mientras duró tuvo a la sociedad sometida a un colaboracionismo forzado por la miseria, en la que las voces críticas que no fuesen silenciadas se encontraban a menudo faltadas de una audiencia preparada para engendrar cambios de calado, sobre todo en el ámbito rural. En este sentido, es significativo el caso de Joaquín Costa, quien en 1902 presentó en el Ateneo de Madrid su famosos memorándum Oligarquía y caciquismo como la forma actual de gobierno en España: urgencia y modo de cambiarla. En dicho texto, Costa señalaba la oligarquía y el caciquismo como principales, si no únicos, problemas de la España del momento. La clase política quedaba definida así como un tumor, una excrecencia antinatural del cuerpo de la nación que había ejercido un poder podrido a través del caciquismo y de las prácticas corruptas, obstruyendo así las fuerzas del progreso, lo que equivalía a tener cautiva a la nación en la servidumbre, la incultura y la miseria. Según su análisis, se requería de acciones drásticas que permitieran extirpar aquella "facción extraña" que era la clase política (aboliendo también las elecciones y el parlamento) para que la nación pudiera redimirse -misión que debía acometerse mediante un cirujano de hierro que se apoyara en las elites intelectuales y económicas para realizar su trabajo. El fracaso inmediato de tal planteamiento se debió, según sus estudiosos, a que "para el electorado campesino el programa de Costa resultaba una construcción demasiado abstracta -lo cual no significa que no fuera comprendido-, o cuando menos lejana. Los logros de su diputado venían siendo, por el contrario, concretos, palpables y cercanos" 5 . A pesar de ello, el mensaje no desapareció del

\footnotetext{
${ }^{4}$ Entre 1878 y 1890 , solamente podían votar unos 800.000 hombres, que eran los mayores de 25 años capaces de pagar una cuota mínima de 25 pesetas al erario de contribución territorial o 50 pesetas de subsidio industrial. A partir de 1891 se reinstauró el sufragio universal masculino, ampliándose el cuerpo electoral a los 5 millones de electores sobre un total de población de unos 17 millones de habitantes.

${ }^{5}$ Carmelo ROMERO SALVADOR; Carmen FRÍAS y Montserrat SERRRANO: "Aragón", en José VARELA ORTEGA (dir.), El poder de la influencia, p. 60.
} 
ideario colectivo, ya que su diagnóstico del caciquismo como gran problema español era compartido por muchos, aunque no hubiera acuerdo sobre cuál era la mejor forma para solucionarlo ${ }^{6}$.

Siendo así, los canales de denuncia de los males del sistema de la Restauración no se circunscribieron únicamente a los espacios de debate político (ateneos, prensa, etc.), sino que la literatura de la época también los trató -ofreciéndonos, hoy en día, un testimonio importantísimo para comprender su funcionamiento-. Como el resto de la sociedad española, los intelectuales y protagonistas de la vida cultural del periodo se habían visto tremendamente impactados por el Desastre de 1898, hasta el punto que después de este trauma nació la que se conocería como "Generación del 98". A pesar de que conformaron un grupo heterogéneo a nivel ideológico, los integrantes de este grupo -que iba desde el conservadurismo de Azorín hasta el individualismo casi anarquizante de Pío Baroja-, compartían una indudable pretensión revitalizadora recogiendo el testimonio de Mariano José de Larra, entre otros. Buscando recuperar una idea idealizada de España -identificada, básicamente, con Castilla- denunciaron en algunas de sus obras los males que padecía el país. Estas serían conocidas como novelas de caciques, que, según José Carlos Mainer, "recibieron, en primer lugar, la herencia de la llamada novela regional decimonónica, y de hecho incorporó a su concepción de la realidad la oscilación entre la visión eglógica y la visión trágica que parecía consustancial a ésta. Pero junto a esta tópica visión del mundo campesino desde la ciudad, la evidente modernización del país, su paulatina incorporación a una sociedad -y a un mercado- unitarios, reveló los abismos de una España ignorada, semifeudal, brutal, patética, cuya atávica influencia lastraba además el futuro de modernización iniciado: entre el regeneracionismo y la complacencia masoquista nació, pues, toda la tradición castiza que había de constituir, en la literatura radical, la más atractiva modalidad del populismo español” ${ }^{7}$.

En el presente artículo analizaremos la obra de cuatro escritores (dos castellanos y dos catalanes) que describieron la naturaleza corrupta del sistema de la

\footnotetext{
${ }^{6}$ Sobre los discursos regeneracionistas de la época, véase Jaume MUÑOZ JOFRE: La España corrupta. Breve historia de la corrupción (de la Restauración a nuestros días, 1875-2016). (Granada: Comares, 2016), pp. 39-42.

${ }^{7}$ José Carlos MAINER, en el prólogo de Doña Mesalina (ed. Madrid: Ediciones Turner, 1975), pp. 18-19.
} 
Restauración. Concretamente, trataremos las dos novelas que gozan de la consideración unánime de la historiografía especializada como las mejores novelas sobre el caciquismo en la España de principios de siglo XX: Jarrapellejos. Vida arcádica, feliz e independiente de un español representativo (1914), de Felipe Trigo, que trata el tema de forma directa; y Doña Mesalina (1910), de José López Pinillos, que ofrece un retrato ambiental. Así mismo, analizaremos tres novelas injustamente olvidadas en este listado de obras de referencia a nivel estatal -probablemente, por desconocimiento idiomático- como son L'hereu Noradell (1889), de Carles Bosch de la Trinxeria, El català de la Manxa (1914) y En Josepet de Sant Celoni (1918), estas dos últimas de Santiago Rusiñol. Las cuatro primeras nos permitirán analizar los efectos del caciquismo en el ámbito rural, con una dominación tradicional, mientras que la quinta nos mostrará esta realidad en un ámbito urbano, el de la Barcelona de principios del siglo XX, una ciudad en plena expansión urbanística, donde los resortes para el control social eran muy menores, pero las oportunidades de enriquecimiento ilícito al calor de la urbanización de nuevas zonas y modernización de los cascos urbanos ya existentes eran lo suficientemente atractivas para seguir perpetuando las malas praxis para conseguir el poder y abusar de él.

Por razones de la extensión requerida para el artículo, lamentamos no incluir un análisis pormenorizado de títulos igual de significativos, como son en el ámbito castellano César o nada (1910), de Pio Baroja; Villavieja (1914), de Manuel Ciges Aparicio; o De horca y cuchillo. Tragedias del caciquismo (1915), de Arturo Mori; entre otras. A nivel catalán, nos habría gustado citar también, para poner solamente dos ejemplos, La Febre d'Or (1892), de Narcís Oller, o Sang Nova (1900), de Marià Vayreda.

\section{El turno o la corrupción institucionalizada}

El sistema de la Restauración funcionó, como comentábamos, alrededor de una alternancia pactada en el poder que también fue conocida como turno dinástico. Ésta se concretaba en la siempre predecible victoria electoral del partido en el gobierno una vez este llevaba un corto tiempo en el poder, habiendo sustituido al anterior por decisión del monarca. La Corona y el poder ejecutivo, pues, tenían una prevalencia 
sobre el poder legislativo que no se correspondía con el carácter teóricamente representativo que se establecía en la Constitución de 1876. Los dos partidos principales, Liberales y Conservadores, vivían en una especie de pacto de no-agresión mutua y aceptaban el papel de árbitro del monarca en los cambios de gobierno. Ramón Villares describe el funcionamiento del cambio en el poder muy afinadamente: "más que gobernar, los primeros pasos de cada nuevo gobierno se centraban en la preparación de las elecciones. [...] En consecuencia, se invertían las tornas de un procedimiento propio del sistema parlamentario. El poder ejecutivo no era un resultado de la voluntad de los ciudadanos, sino de una decisión previa parlamentaria, en la que intervenían varios actores: la corona, los líderes de los partidos y, de forma muy imprecisa, la opinión pública"8, un extremo fácil de corroborar con la lectura de El català de la Manxa (1914), de Santiago Rusiñol ${ }^{9}$. En esa novela, el autor describe el funcionamiento del ateneo del pueblo imaginario en el que sitúa su novela, Cantalafuente. Este ateneo es Ilamado la "Lira Agrícola", y se supone que fue fundado originalmente per unos cuantos entusiastas del arte y unos cuantos campesinos. EI autor explica que, con el paso del tiempo, los fundadores se fueron desentendiendo del proyecto y que "la casa evolucionó y, ahora el maestro, ahora el herrero, ahora el cafetero, ahora el médico, todos los elementos liberales fueron haciéndose socios [de la Lira], y ya sabemos que significaba ser liberal en aquél pueblo: significaba no ser de los otros; significaba seguir los del turno, no armar jaleo $y$, cuando viniesen las elecciones, votar bien encasillado el diputado que les mandasen desde los "Centros oficiales", donde ya sabían bien lo que más convenía a los distritos" ${ }^{10}$.

El resultado adulterado de las elecciones se conseguía, pues, gracias a la manipulación ejercida por una serie de intermediarios -los caciques- que se dedicaban a conciliar los intereses de las clases gobernantes oficiales con las del pueblo, hasta el

\footnotetext{
${ }^{8}$ Ramón VILLARES: Restauración y Dictadura. Volumen VII de la Historia de España (Barcelona: Crítica-Marcial Pons: 2009) dirigida por Josep FONTANA y Ramón VILLARES, p. 98.

${ }^{9}$ Santiago Rusiñol Prats (Barcelona, 1861 - Aranjuez, 1931) fue autor dramático, pintor y escritor. Símbolo del modernismo catalán, a partir de la década de 1900 su obra escrita tomará cierto calado social, aunque esta preocupación sea disfrazada con un marcado tono irónico. Son muestra de ello las novelas Llibertat (1901); L'heroi (1903) y, sobre todo, El català de la Manxa (1914) y En Josepet de Sant Celoni (1918). Para más información, véase Margarida CASACUBERTA: Santiago Rusiñol. Vida, literatura i mite. (Barcelona: Publicacions de l'Abadia de Montserrat, 1997).

${ }^{10}$ Santiago RUSIÑOL: El català de la Manxa, (ed. Barcelona: L’Avenç, 2014), p. 93-94. [Todas las traducciones de Rusiñol y Bosch de la Trinxeria son mías].
} 
punto que este hilo de relaciones fue descrito por Santiago Ramón y Cajal como "el único vínculo que ligaba el campo con la ciudad y el pueblo con el Estado"11. Así lo retrata en Jarrapellejos (1914) Felipe Trigo ${ }^{12}$, escritor que se consideraba a sí mismo como un autor político (aunque, según Carlos Fortea, verlo solamente como novelista social es insuficiente ${ }^{13}$ ). Militante del Partido Socialista Obrero Español desde 1887 (partido fundado en 1879), fue fundador de una de sus agrupaciones en Extremadura. Siendo un miembro activo, pues, del mundo político rural español, el autor realizaba un retrato -según sus propias palabras en la dedicatoria de Jarrapellejos (1914) a Melquíades Álvarez, que acababa de fundar el Partido Reformista y al que el autor le veía posibilidades de gobernar en el futuro-, que no contenía "una historia de una integra realidad, pero sí la de una realidad dispersa, la de la vida de las provincias españolas, de los distritos rurales (célula nacional puesto que Madrid, como todas las ciudades populosas, no es más que un conglomerado cosmopolita y sin típico carácter) que yo conozco más hondamente que usted, acaso por haberla sufrida largo tiempo". Con esta fiel inexactitud, Trigo sitúa en Jarrapellejos una escena en la que el aguacil enseña los edificios del pueblo a dos emisarios del Gobierno que habían acudido a La Joya (pueblo inventado donde se sitúa la acción) para estudiar el fenómeno de una plaga de langostas. Mientras les muestra los edificios más importantes de la población, el aguacil les comenta, con total naturalidad, que el Casino, el Ayuntamiento, el teatro municipal; la luz eléctrica, los rótulos de las calles, el uniforme de los guardias, etc., todo lo ha hecho Pedro Luis Jarrapellejos, "el que lo hace to, el que lo pue to, el amo!", y es que "a pesar de que el conde de la Cruz fuese el alto inspirador de la política, y de sus consejos, y aun en cierta manera de los de Octavio, como joven serio y orientado a la moderna, se oyesen en determinadas ocasiones, don Pedro Luis, campechanote, era el que mandaba, en íntimo contacto con el pueblo. Sin haber querido serlo nunca -

\footnotetext{
11 José VARELA ORTEGA: Partidos, elecciones y caciquismo en la Restauración (1875-1900). (Madrid; Marcial Pons; 2001), p. 413.

${ }^{12}$ Felipe Trigo (Villanueva de la Serena, Badajoz, 1865 - Madrid, 1916). Médico de formación, ejerció en España y en Filipinas, dentro del cuerpo de sanidad militar. Durante su estancia en el archipiélago asiático fue herido de gravedad en una revuelta en el campamento en el que ejercía. A su vuelta a España, esta historia le concedió cierta celebridad. Autor de éxito, sus novelas combinan un marcado carácter de denuncia social (en especial, Jarrapellejos, 1914) con un inusitado atrevimiento en la narración de episodios sexuales -tratándose de principios de siglo XX.

${ }^{13}$ Carlos FORTEA en la "Introducción" de Jarrapellejos (ed. Madrid: Castalia, 2004), pp. 20 y 21
} 
“Pa qué?", contaba el Mocho [el aguacil]-, él hacía y deshacía los diputados y traíalos de coronilla"14.

Un panorama como el descrito nos permite constatar que cuando hablamos de caciquismo -que no era un fenómeno exclusivo de España- lo hacemos como expresión del clientelismo político o patronazgo propio de los sistemas representativos formados por una población con una noción de ciudadanía poco desarrollada -es decir, poco participativa políticamente (la normalidad con la que el aguacil de Jarrapellejos asume que sea una figura no electa la que mande efectivamente en su pueblo, disponiendo hasta los diputados del distrito sin contestación ni necesidad de serlo él es lo suficientemente ilustrativa sobre este punto). Y es que como bien retratan las novelas de la época, la sociedad española de la Restauración tenía una cultura política más basada en la deferencia que en la igualdad, lo que revela que no se trataba todavía de una sociedad de masas sino de clases, con un bajo desarrollo económico y una alta dependencia de las instituciones tradicionales, como eran la familia, la Iglesia o la propia comunidad local a la que pertenecían estos individuos. Aurora Garrido señala que, en los primeros compases de la Restauración, "ruralismo, pobreza [y] dependencia social constituían las condiciones de base sobre las que se asentaba la indiferencia política del electorado, ante sobre todo -como coincidían a señalar distintas fuentes de la época- a sus intereses particulares, familiares y económicos más inmediatos, y cuyo horizonte vital no trascendía, en cualquier caso, el ámbito de lo meramente local” ${ }^{15}$. Los ingredientes para una situación similar se explican a sí mismos en estas estadísticas: en 1890 el 70 por ciento de los españoles vivían todavía en localidades de menos de 10.000 habitantes, mientras en 1900 sólo un 9 por ciento de la población vivía en ciudades de más de 100.000 habitantes. Asimismo, entre 1877 y 1900 la población dedicada al sector primario no bajó del 64 por ciento del total -por solamente un $17^{\prime} 4$ por ciento al secundario ${ }^{16}$. Finalmente, y en

\footnotetext{
${ }^{14}$ Felipe TRIGO: Jarrapellejos, p. 87.

${ }^{15}$ Aurora GARRIDO MARTíN: La Dictadura de Primo ¿ruptura o paréntesis? Cantabria (1923-1931). (Santander: Ayuntamiento de Santander, 1997), p. 20.

${ }^{16}$ Àngel DUARTE, La España de la Restauración, p. 33.
} 
igual nivel de importancia, en 1923, al instaurarse la dictadura de Primo de Rivera, España registraba todavía una tasa de un 52 '35\% de analfabetismo ${ }^{17}$.

A nivel literario, de las cinco novelas aquí estudiadas, cuatro de ellas retratan en profusión el ambiente en que estaba sumido el campo español. Santiago Rusiñol, en su novela El català de la Manxa, explicaba la historia de un anarquista que tenía que huir de Barcelona después de los hechos de la Semana Trágica ${ }^{18}$ y que encontraba refugio en casa de un antiguo compañero de militancia, instalado ahora en un pequeño pueblo imaginario de la Mancha, Cantalafuente. Entre los dos amigos, la camaradería se mantendrá intacta, pero mientras el que lleva más tiempo allí (Ignasi, comercial que se había casado con la hija del amo del café del pueblo) se nos muestra como un hombre completamente adaptado a las pautas de comportamiento social de la España rural, el protagonista del libro (el susodicho catalán) será incapaz de adaptarse a la apatía imperante entre sus nuevos vecinos. Rusiñol, autor marcadamente irónico, muestra el desajuste entre la excitación ideológica del catalán y la realidad social del pueblo, con escenas como la siguiente, donde el protagonista intenta inútilmente promover la toma de consciencia del pueblo:

“- ¿Cuánto ganáis? -les decía.

- Pues... muy poco.

- ¿Qué tal coméis?

- Mal.

- ¿No querríais... trabajar menos y comer mejor?

- Claro que sí.

\footnotetext{
${ }^{17}$ Eduardo GONZÁLEZ CALLEJA: La España de Primo de Rivera: La modernización autoritaria, 19231930 (Madrid: Alianza Editorial, 2005), p. 83.

${ }^{18}$ La Semana Trágica es el nombre con el que se conoce la revuelta antimilitarista y anticlerical acaecida en Barcelona entre el 26 de julio y 2 de agosto de 1909, después de la movilización de unos 40.000 reservistas (la mayoría de ellos catalanes) por el relanzamiento de la aventura colonial en Marruecos (incentivada, en gran parte, por los intereses mineros en el Rif, territorio donde haría negocio el propio monarca y los principales cargos políticos del periodo). El movimiento de protesta nació huérfano de dirección definida y se acabó convirtiendo en un ataque a las instituciones tradicionales, por lo que, entre otros, se destruyeron unos ochenta edificios religiosos en Barcelona. Con el beneplácito de la burguesía barcelonesa, la campaña represiva posterior fue tan intensa como arbitraria: se suspendieron periódicos de izquierdas, se clausuraron 150 centros culturales obreros y escuelas laicas y se sometieron a procesos civiles y militares casi 2.000 personas. Su dureza acabaría generando una campaña de protesta internacional y la caída del gobierno de Antonio Maura.
} 
- ¿Me queréis ayudar a liberaros?

- ¿Qué dice?

- A ir contra el amo.

- ¿Pa qué?

Y este ¿pa qué? le desesperaba, ¡lo encendía! ¡Siempre esclavos! ¡Siempre indiferentes! ¡Siempre tristes y resignados!... Aquél ¿pa qué? fatal que, en oírlo, le sacaba de sus casillas.

- ¿No sentís en vuestras venas la soberanía del pueblo? -les preguntaba, ya fuera de sí.

- No sentimos ná -le contestaban.

- ¿Ni la libertad de consciencia?

- ¿Y eso qué es?

- ¿La libertad?... ¿No sabéis qué es la libertad?... ¿No sentís un cosquilleo en las espaldas, como si os quisieran salir alas, en nombrar ese Santo Nombre?... ¿No os bate el corazón?... ¿No estáis impacientes?... ¿No echáis en falta ese oxígeno?

- Así lo hemos encontrado, y así seguiremos -le contestaban, pacientemente.

- Pero por qué os doblegáis?

- iCon Dios!

Si encontraba alguno que le pareciese que era un poco más despierto, le hablaba de estadísticas que había leído últimamente, y que le habian provocado un lío de números y de sumas que ya no sabía por dónde navegaba.

- ¿Sabéis cuantos analfabetos hay en España?... ¡Pues hay miles!... ¿Sabéis cuantas cooperativas hay en Alemania?... ¡Tantos centenares!... ¿Cuántos obreros sindicados hay en Francia?... Tantos millones, con tal fracción. ¿Y en Italia, y en Bélgica, y en Inglaterra?...

Y aquellos despiertos, que ni lo sabían ni tenían prisa para saberlo, le decían el "¿pa qué?" y el "Con Dios!" y lo dejaban plantado en medio del camino vecinal.

Si encontraba alguno que fuera a misa, le decía:

- ¿Sabéis donde vais?

- A cumplir. 
- ¿Y ya sabéis qué quiere decir... cumplir?

- Pues, cumplir, quiere decir... eso: ir a misa.

- ¿Yya sabéis por qué vais?

- Porque sí... porque todo el mundo lo hace, y porque los padres, que al cielo sean, nos lo enseñaron de pequeños.

- Pero ahora que ya no sois pequeños, sino grandes: hombres, jhombres de Razón!... ¿Si os enseñaran de no ir, también iríais?

- ¡Con Dios! $!^{19}$

Analizando el listado de autores que el anarquista considera pérfidos para la libertad individual (patrón e Iglesia, principalmente), no es de extrañar que Rusiñol concluyera, para definir tanta indiferencia y los activos que la promovían, que "la carcoma de la tradición se había metido tan a dentro que no tenía el suficiente alcanfor toda la sociología y toda la ciencia moderna para arrancar a aquellos campesinos de su oscura ignorancia"20.

Tal y como refleja el diálogo, uno de los principales agentes del mantenimiento del statu quo de la Restauración era la Iglesia católica, institución que gozaba de grandes privilegios en la época. Los retratos humanos de las novelas de Rusiñol y de Bosch de Trinxeria no son tan descarnados como los que aparecen en las novelas de López Pinillos y, sobre todo, de Trigo. En Doña Mesalina (1910), José López Pinillos ${ }^{21}$ otorga al párroco del pueblo un rol destacado en su novela, pero no como pastor de almas sino como protagonista de un flirteo insatisfecho con la maestra del pueblo, Josefina, sobre la que recaerá el mal nombre de "Doña Mesalina" en alusión a Valeria Mesalina, la tercera esposa del emperador romano Claudio, que fue inmortalizada por Suetonio como una persona con una insaciable vida sexual. El cura en cuestión, don

\footnotetext{
${ }^{19}$ Santiago RUSIÑOL: El català de la Manxa, pp. 91-92.

${ }^{20}$ Santiago RUSIÑOL: El català de la Manxa, p. 93.

${ }^{21}$ José López Pinillos (Sevilla, 1875 - Madrid, 1922), periodista, dramaturgo y escritor. Coincidiendo con el cambio de siglo, se trasladó a Madrid, donde su labor periodística, bajo el pseudónimo Parmeno, le granjeó un nombre. El trasfondo regeneracionista (de talante izquierdista, pero sin militancia activa en ninguna organización política) impregnó toda su obra, destacando en la dramática los títulos Esclavitud (1918) o La tierra (1921); en la narrativa breve Cintas rojas (1916). Doña Mesalina (1910) es considerada la mejor novela de las tres que publicó. El ambiente de violencia -soterrada o explícita- que se respira en toda su obra, hace que a menudo se le señale como un autor emparentado con el naturalismo.
} 
Antolín, representará un ejemplo de virtud y bonhomía que contrasta con el de su propia madre, doña Rosa, encargada de la educación de los niños del pueblo que no van a la escuela pública y personaje que ejerce en la novela de censuradora moral acorde con la tradición. Según ella, "con aprender de aquí y de allí no se consigue más que llenar de biento la imaginasión. Lo que se estudia ¿es berdá? Tan berdá como lo que traen los periódicos, que disen que los burros vuelan. [...] Un pescador be un mar, y otro pescador be otro mar, y otro be otro... Pero, ¿bamos a creer que alguien ha hablado con todos los pescadores para escribir la Jografía?... Cuentos de caminos, charranadas y sacadineros. Y así lo demás. ¡La Historia!... Hubo los Reyes Católicos, y la batalla de Clabijo, que ganó Santiago, y por Castilla y Aragón nuebo mundo bio Colón. Pero, ¿los líos que te meten para engordar y engordar el tomo?... Tontita yo si los creyera. Y sin embargo... he llegado a esta edá. No hay más que la Historia Sagrada, porque es sagrada, y el latín, porque sin latín no habría misa. Pero el latín para los hombres. ¿Qué debemos saber nosotras? Debemos saber la Doctrina, coser, sursir, poner el puchero y resar una orasión para cada cosa" 22.

La miseria intelectual de doña Rosa, que acabará la novela siendo la responsable educativa de la inmensa mayoría de los niños del pueblo -doña Mesalina se queda sin alumnos a la vista de su libertina vida sentimental y sexual-, es un muy buen retrato de la sociedad de la ignorancia impulsada también desde la órbita eclesiástica. Y es que como apunta Aurora Garrido, "la influencia de la religión contribuía de manera notable a perpetuar el inmovilismo y la inercia en los ámbitos rurales. Propiedad o explotación minifundista y religión se aliaban, de esta suerte, en la función de preservar el status quo social: una sociedad clientelar que aseguraba el poder social y político de los caciques sobre la base de un ejercicio atemperado de su

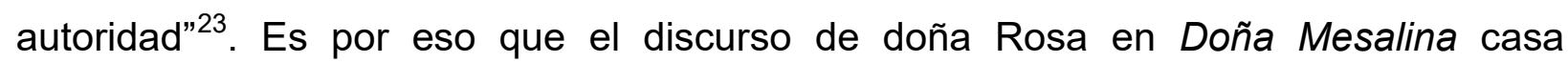
perfectamente con el del cacique del pueblo de Jarrapellejos, quien opinaba que "los braceros no sabían leer, casi ninguno... y era mejor que no leyesen, ante el temor de aficionarlos y que pasasen luego a lecturas peligrosas", aduciendo asimismo que "lo que se afirma desde antiguo acerca de la santidad de la ignorancia es de una exactitud que no desconocería ese ministro de Instrucción, como no la desconocemos los que

\footnotetext{
22 José LÓPEZ PINILLOS: Doña Mesalina, pp. 198-199.

${ }^{23}$ Aurora GARRIDO MARTíN, La Dictadura de Primo de Rivera..., p. 21.
} 
hemos ido recibiendo duras y algo largas las lecciones de la vida. El pueblo no comerá más aunque aprenda gramática en la escuela, y, en cambio, sabrá mejor de su hambre y del hartazgo de los otros"24.

Este es, pues, el marco social desmovilizador propio del caciquismo, que explica la naturaleza de las prácticas políticas desarrolladas entonces, basadas en una acción más clientelar que programática, hecho al cual se corresponde la estructura de los partidos de la época, que no estaban tanto construidos alrededor de un programa como de una figura principal, con las disfuncionalidades que esto creaba. $Y$ es que el clientelismo comportaba un acceso desigual y particularizado a los recursos públicos, lo cual permitía distribuirlos según los intereses del cabeza de grupo, para alimentar y ampliar así su red de influencia, normalmente al margen del interés y beneficio general. De tal manera, estos recursos salidos del presupuesto estatal podían destinarse tanto a la compra directa de votos como a favores indirectos, como podían ser la realización de obras públicas con fines electoralistas y que supusieran el beneficio privado de ciertos amigos políticos. Para ilustrar la dimensión del fenómeno del clientelismo político del periodo, los datos y anécdotas aportados por Ramón Villares nos resultan muy útiles: "la petición de favores era tan común, que se ha calculado que más de un tercio de los epistolarios conocidos de figuras políticas de la Restauración está compuesto por cartas de recomendación, activa o pasiva. $Y$ en su mayoría se concentran en el entorno temporal de la celebración de elecciones; primero, con la petición de votos, y después, la concesión cuando posible de los favores pretendidos." Así mismo, "de la casa de Sagasta en Madrid se decía que carecía de puertas, pues era un continuo flujo de visitas vespertinas $\mathrm{y}$, con otro estilo, algo similar sucedía en el domicilio conocido como "La Huerta" donde residían Cánovas y su influyente segunda esposa, Joaquina de la Osma. Pero visitas y comisiones eran algo más que expresión de deferencia o pleitesía, así como teatro para practicar el viejo oficio de pretender. Su objetivo era lograr, además de los consabidos turroncillos ${ }^{25}$, compromisos más amplios de apoyo para mejoras y obras públicas en el distrito, hasta el punto de acuñarse la denominación de carreteras parlamentarias para las conseguidas por este

\footnotetext{
${ }^{24}$ Felipe TRIGO: Jarrapellejos, pp. 131 y 210.

${ }^{25}$ Concesiones económicas del presupuesto público.
} 
procedimiento"26. Y es que como ahonda Moreno Luzón, "es frecuente que el clientelismo político incluya prácticas corruptas, tales como librar del cumplimiento del servicio militar a un individuo apto por recomendación de un cacique, pero también abarca muchas otras que no lo son, como el trazado de una carretera por las fincas de un político o la creación de un puesto innecesario para hacer un favor. Existen también actos de corrupción que no tienen nada que ver con el patronazgo, como el enriquecimiento personal del ocupante del cargo" ${ }^{27}$.

Todo esto es visible, por ejemplo, en la novela L'hereu Noradell (1889), de Carles Bosch de la Trinxeria ${ }^{28}$. Según nos cuenta el filólogo Jordi Castellanos, se trataba de uno de los autores más representativos del momento, que se convirtió en un verdadero mito en la configuración del cual se mezclaban elementos personales y patrióticos, al ser visto como una especie de encarnación de las formas naturales de vida, representando las esencias de la montaña catalana, no contaminadas todavía por la civilización moderna. Siguiendo al estudioso, la obra de Bosch de la Trinxeria, a decir verdad, "era una formulación ingenua y pura de la ideología conservadora de la Renaixença, propuesta del catalanismo no político, consistente en un retorno a las formas de vida del Antiguo Régimen -con las costumbres patriarcales y la religión como cimientos- que veía conservados en algunos sectores del mundo rural”29. L'hereu Noradell contenía, pues, amplios trazos de denuncia de los males del sistema político de la Restauración. En él, Marçal Noradell, el protagonista, se convertirá en diputado gracias al empuje "de toda la clase rica conservadora de Figueres", que le permitirá derrotar al candidato del gobierno -más adelante veremos con qué métodosa pesar de no tener "ninguna influencia" al haber vivido siempre "aislado de la política", circunstancia que hará que el muñidor de votos del candidato oficialista hable de él en un meeting electoral de la siguiente manera, "alzando la cabeza con orgullo y sonrisa

\footnotetext{
${ }^{26}$ VILLARES, Restauración y Dictadura, pp. 105-106 y 118

${ }^{27}$ Javier MORENO LUZÓN: Romanones. Caciquismo y política liberal. (Madrid: Alianza Editorial, 1998), p. 74 .

${ }^{28}$ Carles Bosch de la Trinxeria (Prats de Molló, Vallespir, 1831 - La Jonquera, Girona, 1897). Escritor. Proveniente de una rica familia de propietarios rurales, fue un muy buen conocedor del Pirineo catalán y francés. Emparentado con el mundo cultural conservador catalán de La Renaixença, el éxito cosechado con sus relatos cortos (recogidos en Pla i muntanya,1888; De ma collita, 1890; etc.) le llevó a aventurarse en el campo novelístico con L'hereu Noradell (1889), considerada como su mejor novela. Casi toda su obra está centrada en el mundo rural, aunque también realizara un intento de descripción del mundo urbano (L'hereu Subirà, 1893), considerado hoy en día una novela fallida.
}

${ }^{29}$ Jordi CASTELLANOS: "Carles Bosch de la Trinxeria i la novel·la", Serra d'Or, XIV (1972), pp. 489-491. 
sardónica- ...Y ahora, responded! ¿Qué os ha propuesto el candidato de la oposición? Nada... ¡Nada os puede prometer! Nadie lo conoce en Madrid. Cerca del gobierno será un desconocido. Un Don Nadie; volverá tal como se fue, y os quedaréis frustrados, sin haber obtenido nada: pagaréis las mismas contribuciones, más o menos. Vuestro camino será siempre de herradura, y vuestra fuente soltará agua vete a saber tu cuando. Dejaros de esas ideas que predica el candidato de la oposición, de eso a lo que llaman catalanismo o regionalismo, que nadie sabe qué significan... Son tonterías. Todo es música celestial", mientras que el candidato del gobierno podía hacer auténticos milagros, como sanar el campo ampurdanés de la filoxera: "no lo dudéis, no, que vuestro futuro diputado, ayudado por el gobierno, lo hará desaparecer. [...] Sí, lo hará desparecer. Él solo lo puede hacer. Y así volverán la riqueza y la prosperidad a esta comarca. [...] No tengo necesidad de deciros que la cuestión de la fuente y carretera ya la podéis tener por concedida. En cuando a la rebaja de la contribución, también podéis contar con ello, puesto que se harán todos los medios para obtenerla"30. A pesar de su triunfo electoral contra pronóstico, Marçal, al cerrarse la primera legislatura, parece corroborar los augurios del muñidor del candidato oficial y vuelve a su casa con la intención de dimitir. Así expone el problema a los que le han aupado al cargo parlamentario: "Pero señores, mi representación no sirve para nada. Yo no soy de ningún partido, soy catalán, catalán de corazón. [...] De verdad se lo digo: ¡se podría aplicar a la capital castellana aquello de Roma veduta, fede perduta! [...] Desgraciado el que se encuentra mezclado en medio de aquellos partidos heterogéneos guiados solamente por la ambición del poder!". Finalmente convencido para no desistir, al volver a Madrid, el protagonista deja atrás sus reparos y se une al Partido Conservador, "atraído por los halagos de los jefes aquél partido". Esto le llevará a perder su "buen criterio catalán que lo distinguía al principio. Había sido contagiado por el brillante floreo de nuestros hombres de Estado". Una transformación total: "ya no escribe más en catalán, habla y escribe en castellano a sus electores ampurdaneses [que no entienden este idioma]...", para acabar convertido en un político típico del periodo, despreocupado del interés general, solamente pendiente de su bienestar

\footnotetext{
${ }^{30}$ Carles BOSCH DE LA TRINXERIA, L'hereu Noradell, (ed. Barcelona: Edicions 62, 1979), pp. 43; 49 y 48.
} 
personal: "¿qué le importan la ruina, la filoxera? Si su partido sube al poder, ¿acaso no encontrará un buen destino en Cuba o en Filipinas, donde ganará una fortuna?" ${ }^{31}$.

Como atestigua la despreocupación de Marçal Noradell -y, como veremos más adelante, el ejemplo de otra novela de Santiago Rusiñol-, una de las vías tradicionales de satisfacción de las clientelas políticas era la colocación masiva de amigos o fieles en puestos de la Administración pública. Después de las espectacularmente sucias elecciones de 1876, un diplomático británico testimoniaba "del más alto al más bajo, tanto en la capital como en provincias, gobernadores, diputados provinciales, concejales, funcionarios, porteros, barrenderos, todos y cada uno de quienes tenían un puesto y un sueldo en el momento de la proclamación del Rey, [fueron] despedidos para hacer sitio a un alfonsino"32. La plasmación de que esta sería una práctica usual, independientemente del color del partido en el gobierno, la tenemos desde un buen inicio en el dato del primer gobierno Sagasta (1881-1884), en el cual se produjo una avalancha de cesantías para dar cabida en el cuerpo funcionarial a la clientela propia: 570 nuevos nombramientos y ascensos en los dos primeros meses de gobierno, según la gaceta oficial ${ }^{33}$. Como anunciábamos, Santiago Rusiñol hace un muy buen retrato de lo que suponía la colocación de adeptos en su libro El català de la Manxa. En un momento en que el hijo del protagonista flirtea con una chica, esta le cuenta su vida: "Había nacido, como tantas, en una familia distinguida, la cual, por azares de la vida, había entrado en decadencia. Había tenido un padre empleado en un Ministerio, como sus tíos, como sus hermanos, y como todos los de su casa. Por el solo hecho de tener un padrino, que era jefe de facción, había ido colocando a toda la parentela, y en su casa se podía decir que eran unas oficinas. Eso sí, eran empleados mientras él estaba en el poder; pero, cuando caía, y caía muy a menudo, caían todos como soldados de cartas, y la miseria que pasaban solo la podía saber aquél que se encontraba en una situación similar. Había muchos días en que solamente comían gazpacho y pan bañado en vino, que iban vestidos con las sobras de la ropa de todos ellos, y como no

\footnotetext{
${ }^{31}$ Carles BOSCH DE LA TRINXERIA, L'hereu Noradell, pp. 89, 92 y 100-101.

${ }^{32}$ Citado en José VARELA ORTEGA: Partidos, elecciones y caciquismo..., p. 150.

${ }^{33}$ Ramón VILLARES, Restauración y Dictadura., p. 70
} 
había de sobras, siempre alguien de la familia tenía que quedarse en la cama esperando que el otro volviese, o que cayese el ministerio..."34.

A escala local, este esquema de colocaciones por fidelidad y no por capacidad se reproduciría. Felipe Trigo, en Jarrapellejos, lo ilustra con distintos casos, entre ellos el de uno de los personajes más siniestros del pueblo, apodado El Gato, quien rehace su vida gracias a que el Ayuntamiento le asigne un sueldo de dos pesetas diarias como conserje de la prisión municipal "y es claro que, habiéndola judicial, no tenía que guardar nada) tan pronto como hubo vuelto del presidio. Diplomático sistema del cacique, el gran Jarrapellejos, del hombre que sabía quedar bien con todo el mundo: a los amigos que se arruinaban al monte los nombraba alcaldes, secretarios, administradores de consumos, a fin de que pudieran reponerse; a los ladrones y asesinos los domaba en simpatías, habiéndoles guardar las vidas y haciendas de los otros. Gente de cuidado, no obstante, don Pedro Luis era el primero en darles unos duros al verlos aparecer por las tinieblas. En eso consistía el sueldo del Gato, aumentado ahora con su suplemento de diez reales, asimismo del Municipio, como guarda de las eras" ${ }^{35}$. La descarnada mirada de Trigo hace que al final del libro, por tal de tapar su participación en un crimen que habría deshonrado a las dos principales familias del pueblo (los nobiliarios de la Cruz y la caciquil Jarrapellejos), el cacique ordene que uno de los culpables se convierte en Gobernador Civil de Badajoz y el otro en alcalde del pueblo, La Joya. Al único testigo que les podría haber involucrado en el crimen, se le recompensa por su silencio con el cargo de guarda de la cárcel, y al evidentemente inútil juez que se ha prestado a archivar el caso en vistas de quienes eran los auténticos culpables, se le retribuye con un ascenso. $Y$ es que el control de la Justicia por parte de los agentes caciquiles fue una de las características de la Restauración española, hasta el punto que -como explica Pedro M. Egea Bruno- en la Murcia de la Restauración la impunidad de que gozaban los protegidos de los caciques regionales frente a los órganos judiciales hizo que se acabara acuñando la expresión "mata al rey y vete a Murcia". Como nos detalla este historiador, "la Administración de justicia se reveló indispensable para allanar obstáculos -suspendiendo ayuntamientos y procesando concejales de la oposición-, servir a los amigos políticos y favorecer a

\footnotetext{
${ }^{34}$ Santiago RUSIÑOL: El català de la Manxa, p. 153.

${ }^{35}$ Felipe TRIGO: Jarrapellejos, p. 115.
} 
individuos del lumpen, necesarios en los empeños violentos. Si el sufragio universal obligó a multiplicar los arbitrios para asegurar el fin apetecido, la institución del jurado restablecido en 1888- permitió condicionar los veredictos en el sentido deseado. Nada escapó a las intrigas, desde mediar en la elección de sus miembros a proveer en su corrupción, sin olvidar la recusación de jueces díscolos, el manejo de tiempos procesales, el soborno de testigos o la compra del perdón"36.

\section{Caciques, muñidores y elecciones}

Como nos enseñan literariamente los casos de Jarrapellejos o de las clases potentadas de Figueres en el caso de L'hereu Noradell, la España de la Restauración no estaba completamente dominada por los intereses del poder central, sino que desde el ámbito provincial hubo un intenso intento de influir y formar parte de las decisiones de una estructura de poder centralizada. Con el paso del tiempo, se producirá un fortalecimiento de los poderes locales frente al central, constatable por el aumento de los llamados distritos propios de una familia o sección. Eso llevó a una disminución paulatina de los llamados diputados cuneros, que salían de las circunscripciones donde no había ninguna facción con la suficiente fuerza para imponer a un candidato propio (también llamadas distritos disponibles), donde el ministerio de la Gobernación podía colocar al candidato que le conviniera, sin necesidad de que este tuviera relación previa con su nueva circunscripción. En L'hereu Noradell, la presentación del diputado cunero que lucha electoralmente con el protagonista es especialmente significativa: "nadie lo conocía; no entendía ni una palabra en catalán. Nunca había estado en el Empordà. El gobierno de Madrid lo había impuesto al país. Era sobrino del hijo de un primo de la mujer de un tío del ministro de Fomento", tal como es ridícula la presentación que le hace su intermediario: "A pesar de que sea castellano es catalán de corazón, amante de nuestra tierra como si hubiera nacido aquí. Enterado y dispuesto a atender vuestras necesidades. Él, mejor que ningún otro lo puede hacer, ya que es a la fuente [de los recursos] y amigo de los que tienen la sartén por el mango. Solamente él os hará obtener todo lo que hasta ahora

\footnotetext{
${ }^{36}$ Pedro M. EGEA BRUNO, "Mata al rey y vete a Murcia. La corrupción de la justicia en la España de la Restauración", Studia historica: Historia contemporánea, 33, 2015, p. 160.
} 
habéis pedido"37. A pesar de su proximidad al poder, estos diputados no respondían siempre a los intereses de sus representados. Siendo así, no es extraño que las clases potentadas de la región se inclinen por buscar un candidato alternativo de la tierra, ya que como se le expresa a Marçal Noradell en una reunión de propietarios: "ya es hora que nuestro diputado sea ampurdanés. Ya tenemos bastante de diputados extraños a la tierra, impuestos por el gobierno, quien, una vez elegidos, no se acuerdan nunca más de nosotros" ${ }^{\prime 3}$.

El resultado de esta tensión entre centro y periferia ${ }^{39}$ es que los parlamentarios acababan no formando un bloque homogéneo, sino ejerciendo básicamente de intermediarios entre el poder central y sus respectivos distritos electorales, siendo cada vez mayor el tiempo que tenían que invertir en atender las peticiones de su electorado ${ }^{40}$. Los caciques no tenían una condición económica determinada -podían ser pequeños propietarios agrícolas, secretarios municipales o comerciantes, a escala local- sino que sus características determinantes eran la influencia y el arraigo. Se trataba de jefes locales, más que de partido -su adscripción podía cambiar de unas elecciones a otras-, que controlaban un área electoral -de su tamaño dependía la posición del cacique en la pirámide política del sistema-, conseguido gracias a la obtención de beneficios privados y comunes mediante la manipulación del aparato administrativo. Así se generaban casos como el cántabro, extrapolable a gran parte del conjunto de España: allí "fueron los diferentes estratos de la clase media provincial rural y urbana los más beneficiados por este tipo de clientelismo, constituyendo la auténtica base social sobre la que sustentaría el sistema político de la Restauración [...]. Ella monopolizó las instituciones de gobierno a nivel nacional (representación en las Cortes), provincial y local, de ella se nutrió, esencialmente, la organización caciquil de la provincia". Así mismo, existía "un sistema de seguridad a través de la dependencia de las elites locales. Éstas se identificaban preferentemente con la

\footnotetext{
${ }^{37}$ Carles BOSCH DE LA TRINXERIA: L'hereu Noradell, p. 45.

${ }^{38}$ Carles BOSCH DE LA TRINXERIA, L'hereu Noradell, p. 42.

${ }^{39}$ Resuelta con la entente cordiale entre intereses que Mercedes Cabrera y Fernando del Rey Reguillo han acertado en denominar instrumentación recíproca.

${ }^{40}$ En casos en que mantener la proximidad fuera complicada, como el de las Canarias, durante los periodos electorales, los periódicos afines no informaban de ningún compromiso adquirido por el candidato, sino que enumeraban el listado de favores individuales o colectivos proporcionados durante la legislatura anterior. José VARELA ORTEGA (dir): El poder de la influencia, p. 566.
} 
referida clase media propietaria (hacendados agrícolas o ganaderos, comerciantes, industriales) e ilustrada de profesiones liberales (abogados, médicos, farmacéuticos, veterinarios, sacerdotes, etc.), cuyo poder político era consecuencia de su preeminencia social" ${ }^{41}$.

Uno de los principales barómetros con los que contaban las clases dominantes de la sociedad de la Restauración para saber el capital de poder acumulado por cada actor en la vida pública y política eran las convocatorias electorales que se iban sucediendo. Como ya hemos indicado, las elecciones de 1876 -las primeras del turnismo- fueron groseramente sucias, poniéndose de manifiesto el diseño gubernamental (a cargo del ministro de la Gobernación, Romero Robledo) en detalles tan evidentes como el conocimiento previo que tenían los partidos republicanos de que no obtendrían ningún escaño -adversidad que sólo pudieron sortear media docena de candidatos con el suficiente arraigo en sus distritos- o el hecho de que hubiera candidatos conservadores que no consiguieron ser elegidos en distritos en los que no había una competencia fuerte -el partido Liberal no se fundó hasta 1880-, dejándose estos puestos en manos de candidatos opositores al servicio de caciques. En ninguno de los comicios electorales del periodo dejó de haber una activa manipulación gubernamental, y había veces en las que los resultados electorales ya se sabían -y hasta aparecían en el periódico- antes de que se realizara la votación. El único cambio registrado fue el del nivel de influencia a partir del cambio de sufragio: con la imposición del sufragio masculino universal en 1890, las organizaciones locales de los partidos -los caciques- pasaron a tener más peso en el resultado de las elecciones que cuando había sufragio censitario ${ }^{42}$. Y es que el diseño del encasillado necesitaba, para concretarse, la movilización de una maquinaria electoral que englobaba desde el gobernador civil al notable local o provincial que coordinara los amigos políticos del distrito, pasando por la administración local y la Justicia. Uno de los puestos clave en esta batalla era el de gobernador civil, al que se llegaba por la adscripción a un partido, no por méritos profesionales: era un cargo puramente político, no meritocrático ${ }^{43}$. En

\footnotetext{
${ }^{41}$ Aurora GARRIDO MARTín, La Dictadura de Primo de Rivera..., p. 20.

42 José VARELA ORTEGA, Partidos, elecciones y caciquismo..., p. 469

${ }^{43}$ La crisis creciente del sistema a partir del Desastre de 1898 acentuó esa tendencia: será necesario someter a un mayor control político la figura del gobernador civil con tal de que siguiera organizando las
} 
ocasiones, no obstante, nos encontramos que el hombre que ocupaba tal puesto no lo hacía por sintonía con la administración central, sino que había sido colocado directamente por el "padre o padrastro de la provincia", que lo tenía "como mandatario o delegado de su omnipotencia local" ${ }^{44}$.

Los intereses de todos estos actores se dirimían, como decíamos, en las contiendas electorales, en las que se influía de formas diversas. Las redes del clientelismo político en la España de finales del siglo XIX funcionaban mediante tres instrumentos complementarios: la circunscripción electoral, normalmente uninominal, diseñada habitualmente para favorecer el peso del electorado rural sobre los distritos urbanos de orientación republicana ${ }^{45}$; el encasillado elaborado desde el ministerio de la Gobernación, consistente en la colocación de cada candidato en un escaño (casilla) previamente acordado entre los partidos -el partido vencedor normalmente ocupaba un 65 por ciento de los escaños en el nuevo Parlamento-; y la movilización de recursos públicos para garantizar la elección del candidato deseado, mediante votación o sin ella. La adulteración del resultado electoral -hecha normalmente de forma preventiva- podía realizarse ya fuera mediante la negociación, la corruptela o el uso de la violencia. Para llevarlo a término se recurría al pucherazo o tupinada, es decir, a la alteración del censo, suponiendo a veces la exclusión de hombres que cumplían los requisitos para tener derecho a voto o, en cambio, la inclusión (y voto) de muertos en el censo o la suplantación de electores -las cuadrillas de votantes, que se desplazaban por diversos pueblos en un día votando de forma repetida al partido gubernamental. Si tenemos en cuenta que la depuración del censo de Barcelona impulsada por el alcalde Bartomeu Robert (más conocido como el "Doctor Robert") supuso la eliminación de 27000 electores falsos ${ }^{46}$, podemos hacernos a la idea de la impunidad con la que

elecciones y repartiendo los cargos en su provincia a gusto de las autoridades. José Luis GÓMEZNAVARRO, El régimen de Primo de Rivera (Madrid: Cátedra, 1991), p. 188

\footnotetext{
44 José VARELA ORTEGA, Partidos, elecciones y caciquismo..., p. 411. En casos donde el gobernador debiera su posición a la proximidad al cacique poderoso podía llegar a recordar al ministro de la Gobernación que el alcalde de la provincia también debería ser elegido por el cacique; como en el caso de Guadalajara en 1901. Javier MORENO LUZÓN, Romanones, p. 138.

${ }^{45}$ No es ninguna casualidad que la industriosa Cataluña acabara siendo el territorio más subrepresentado del periodo, frente a la sobre-representación gallega, por ejemplo. Carlos DARDÉ et al: "Conclusiones" en José VARELA ORTEGA (dir): El poder de la influencia, p. 562.

${ }^{46}$ Cifra proporcionada por Borja de RIQUER, que remarca que a partir de aquél momento ya no salió elegido ningún diputado monárquico en la Ciudad Condal. Información recogida en su prólogo "Propietaris, advocats i polítics. Els gestors de la gran Barcelona" al libro de Celia CAÑELLAS y Rosa
} 
durante un tercio de siglo se habían manipulado los resultados electorales en una urbe politizada como la Ciudad Condal ${ }^{47}$. A veces se llegaba al extremo en que figuraran más votos que habitantes en un pueblo. Otro sistema eran las circulares que el mismo gobernador mandaba a las autoridades locales recordándoles cuál era la candidatura que contaba con la simpatía del gobierno.

La preparación de unas elecciones no se hacía a escondidas, sino que, como atestigua el siguiente intercambio de telegramas entre el Gobernador Civil y el Ministerio de la Gobernación en ocasión de las elecciones de 1880 en el distrito electoral de Olot (Girona), constituían auténticas negociaciones entre los poderes fácticos de la zona y el Gobierno:

10 de enero [Del Gobernador Civil al Ministerio de Gobernación]: "Mañana llamaré a algunas personas influyentes de aquel distrito para preparar el terreno electoral".

15 de enero [Del Gobernador Civil al Ministerio]: "He conferenciado con algunos electores influyentes de Olot. No tienen preconcebida ninguna candidatura, aunque han hablado con agrado de Don Eduardo Casanova, joven abogado y hacendado rico del país, e hijo del brigadier de ingenieros a quien Olot debe reconocimiento (...). Si surgiera un nombre que apoyara con cierta autoridad el proyecto de ferrocarril de Tortellá a Olot no habría medio de combatirlo. Me ofrecieron no comprometer su palabra por nadie, sin el beneplácito del Gobierno, a quien desean complacer, siempre que se trate de alguna persona que tenga algunas afecciones o raíces en el país, y no sea desconocido o pugne con sus intereses".

18 de enero [Del Ministerio al Gobernador Civil]: "Redoble Usted sus esfuerzos para desbaratar toda candidatura que no sea la que yo le indique en el distrito de Olot".

20 de febrero [Del Ministerio al Gobernador Civil]: "Me proponen los diputados como el mejor candidato de Olot al diputado provincial Sr. Torroella. Estoy dispuesto a aceptarlo con mucho gusto, como aceptaré cualquiera que sea adicto al Gobierno, pero lo que no puedo aceptar es al Sr. Casanova, y lo que me sorprende es que, después de seis años de dominar en la provincia las mismas influencias, ofrezca tantas dificultades vencer en un distrito rural. Creo que Usted moralmente está más comprometido que nadie en evitar al gobierno un disgusto y un desengaño".

TORAN: Els governs de la Ciutat de Barcelona (1875-1930): Eleccions, partits i regidors. Diccionari biogràfic. (Barcelona: Ajuntament de Barcelona, 2013), p. 10.

47 Barcelona tenía en 1900537.354 habitantes, según el censo municipal (recuperado de http://www.bcn.cat/estadistica/catala/dades/anuari/cap02/C020101.htm -consultado el 1/VI/2017). 
29 de marzo [Del Gobernador Civil al Ministerio]. "Ayer quedaron constituidas todas las mesas del distrito electoral de Olot con personas adictas. No hay oposición".

12 de abril [Del Gobernador Civil a Ministerio]: "Ha sido proclamado diputado a Cortes por el distrito de Olot Don Salvador Torroella y Marimón por 575 votos, sin contrincante ${ }^{\text {A8 }}$

Sobre las trampas en la lucha electoral nos sobran ejemplos, tanto en la prensa $^{49}$ de la época como en la literatura. De las cinco novelas analizadas, tres de ellas narran cómo se preparaban y cómo era el día de unas elecciones. Tanto en el ámbito rural como en el urbano, el trabajo previo era indispensable para conseguir un resultado positivo. Por eso, en L'hereu Noradell encontramos que "al saber el gobierno [de] la candidatura de oposición patrocinada por muchos electores de Figueres, se preparó enseguida para derrotarla. El comité oficial envió emisarios por los pueblos, anunciando la llegada del candidato agradecido por el gobierno, excitando empleados, alcaldes, etc., para hacerlo triunfar a todo coste. El candidato castellano que hizo de oposición a Marçal se presentó a Figueres acompañado de sus ayudantes de elecciones, caciques, empleados, toda la seguidilla de gente que cobra o que espera turrón, auténticas sanguijuelas que chupan toda la sangre al contribuyente". En el caso de esta novela, nos parece especialmente interesante el retrato que realizaba Bosch de la Trinxeria de estos muñidores de votos. El candidato oficial tenía su "sabueso", que "era un personaje: el señor Jofre. Un señor particular sin oficio ni beneficio que había sido zapatero en la portería del señor Desplà, y que ahora vivía de renta. Empresario de elecciones oficiales, siempre dispuesto a servir al gobierno, cualquiera que fuese, que le diese huesos a roer. Unos cincuenta años; lleva un sombrero raído y levita larga, reluciente de tanto servir. Es su uniforme oficial que se pone solamente los días de elecciones para presentarse y apoyar al señor diputado. Lánguido, cara

\footnotetext{
${ }^{48}$ Recogidos por José VARELA ORTEGA en su artículo "Los amigos políticos: Funcionamiento del sistema caciquista", Revista de Occidente, n. 127 (1973). Querría dar las gracias a Antoni Mayans, director del Arxiu Comarcal de la Garrotxa, por hacerme llegar esta información.

${ }^{49}$ Para poner solo un ejemplo, el periódico La Voz de Alicante resumía episodios de este tipo en elecciones de marzo de 1905 así: "El cuerpo electoral, al que se ha enseñado lo suficiente para que sepa que debe abstenerse de votar, anduvo no ya retraído sino huido, de manera que el que lograba pescar a un elector le faltaba tiempo para meterlo en un coche y llevarlo al colegio (...) De incidentes no hablemos: palos a primera hora en Alicante. Presidentes de mesa ... que echan a correr con las actas en blanco", etc. Citado por Salvador FORNER y Mariano GARCIA: Cuneros y Caciques (Alicante: Patronato Municipal del V Centenario de la Ciudad de Alicante, 1990), p. 139
} 
afeitada, de mirada viva, avispado, muy listo, la prueba es que vive como un señor sin hacer nada. Se dice amigo de los diputados, que se cartea con ellos. [...] Los estanqueros y alcaldes de pueblo lo temen y respetan. ¡Llamadle tonto! ¡Cualquiera se ponga a hacer zapatos! ${ }^{50}$.

Una de las características más remarcables de las luchas electorales del periodo es que los candidatos renovadores realizaban las mismas trampas que los oficiales. Esta la vemos claramente, de nuevo, en L'hereu Noradell y en En Josepet de Sant Celoni. En el primer caso, el protagonista, "al ver lo de siempre, un desconocido, extraño a la tierra, impuesto por el gobierno centralizador de Madrid, acudió a los mismos medios empleados por este. Recorrió los distritos, ayudado por sus amigos, presidió reuniones electorales, invocando los intereses del país, hablando a todos clar i català $^{51}$. En una palabra, fue tanta su actividad que venció a su contrincante, resultando elegido con gran mayoría"52. Igualmente pasaba en el ámbito urbano, como se explica en la novela de Santiago Rusiñol En Josepet de Sant Celoni (1918), en la que se nos describe la vida de un aventurero sinvergüenza que después de un peculiar recorrido vital se hace rico estafando a sus socios en un comercio de venta al detalle de Barcelona y decide presentarse a las elecciones municipales, como candidato independiente, aprovechando el calor renovador que había supuesto la irrupción de la Solidaridad Catalana ${ }^{53}$. Josepet, planificando la contienda electoral, dice que "el mal fue que en mi barrio había dos candidatos más: uno de liberal conservador y otro de liberal sin conservar, que también estaban dispuestos a sacrificarse por el pueblo, y tuve de prepararme de luchar con ellos para saber quién iría con más valor y abnegación al sacrificio. A mí ninguno de los dos me inspiraba miedo. Ya habian sido concejales en otras ocasiones y tenían casinos de aquellos que suelen tener piso, sello, conserje, y sala de juntas, pero que el día de votar salen votantes de debajo el tintero; tenían las fuerzas vivas... Pero en cambio yo tenía una, que no me la podían

\footnotetext{
${ }^{50}$ Carles BOSCH DE LA TRINXERIA, L'hereu Noradell, p. 45.

${ }^{51}$ Expresión catalana que significa hablar claro, sin divagaciones innecesarias.

${ }^{52}$ Carles BOSCH DE LA TRINXERIA, L'hereu Noradell, p. 53.

${ }^{53}$ Movimiento político transversal nacido en 1906, bajo el impacto todavía del impune asalto militar a la redacción de la revista satírica Cu-cut! de 1905 y con la lucha contra la represiva Ley de Jurisdicciones como gran aglutinante. Bajo un programa común, las distintas formaciones políticas que se unieron en la Solidaridad Catalana obtuvieron un éxito extraordinario en las elecciones provinciales y generales de 1907.
} 
quitar: tenía la fuerza del beber, la amistad de tantos taberneros que me conocían de aquellos tiempos, de tantos jugadores metidos por todos los antros del barrio, de tantos valientes como todavía quedan, gracias a Dios, en aquellos foyers... Y entre los suyos y los míos nos lo haríamos; que si ellos querían hacer correr sangre, yo haría correr vino; y veríamos quién tiene más fuerza: el jugo bruto o el jugo de la uva, los asalariados o los bebedores, los caciquitos falderos o los de Josepet de Sant Celoni" ${ }^{54}$. Este desafío se concreta el día de las elecciones, "Y que la lucha fue feroz, os doy fe con mi rúbrica. Reíros de la nigromancia, de la cartomancia, comparadas con el jaleo que se montó en aquel distrito. El batallar de aquellos escamotes fue un juego de manos colectivo, que empequeñeció los hechos más gloriosos de aquél tipo de controversias. Aquello era la fuerza bruta jugando contra el ingenio y viceversa. Unas termópilas municipales y un ball de bastons ${ }^{55}$ que se bailaba a todas las puertas $y$ portezuelas del Templo de la Legalidad. Si ellos hacían votar un difunto, nosotros un antepasado; si ellos hacían ruedas, nosotros sardanas ${ }^{56}$; si ellos en un momento de distracción tiraban un fajo de papeletas, nosotros un saco lleno. Elector tuve que votó primero con barba, después con bigote y después afeitado como un cómico. Urna hubo que se encendió por el sistema de un papel químico que venía a ser un torpedo para aquellas urnas acorazadas, y acta hubo que se firmó en negro... con agua y con polvos, que cuando caían se convertían en blanco. El hecho era este: que [aquellas elecciones] dieron vida al vecindario una semana entera, que gracias a aquellos acontecimientos hubo muchas familias que comieron caliente durante quince días $y$ que hubo bebedores que se tambalearon medio año. El hecho fue que dando miedo a los unos, haciendo beber a los otros y excitando a todos, solamente con cinco o seis heridos (que se los curó cada uno el suyo), obtuve el acta más limpia que surgida de los comicios en aquel momento de la historia; que había ganado por derecho legítimo, que entré en el pleno municipal y que se me proclamó concejal de la ciudad de Barcelona" ${ }^{57}$.

\footnotetext{
${ }^{54}$ Santiago RUSIÑOL: En Josepet de Sant Celoni, pp. 136-137.

${ }^{55}$ Danza popular tradicional catalana, en la que los palos ("bastons") juegan un rol protagonista, al hacerlos chocar entre ellos los bailadores siguiendo el compás de la música. Coloquialmente, esta expresión se usa para referirse a una batalla campal.

${ }^{56}$ Danza popular tradicional catalana, en la que los participantes bailan en círculo.

${ }^{57}$ Santiago RUSIÑOL: En Josepet de Sant Celoni [1918] (ed. Barcelona: L’Avenç, 2016), p. 140
} 
En el caso de Jarrapellejos es interesante observar que no se podían ganar unas elecciones sin utilizar los mismos métodos fraudulentos que los contrincantes hasta las últimas consecuencias. El día de los comicios, Octavio, que a pesar de ser ahijado del cacique se presenta a las elecciones creyendo en la causa del cambio social, "iba recibiendo noticias. Triunfo, triunfo a pesar de los intentos de coacciones y de los sendos estacazos a última hora repartidos por "partidas de la porra" que capitaneaban el Gato, el Mocho, Zig-Zag...", ante lo que Octavio en persona acude al colegio electoral y se enfrenta a los malhechores (personajes gemelos al muñidor Jofre, de L'hereu Noradell). Cuando cierre el colegio electoral, Jarrapellejos hace Ilamar a Octavio. El cacique le comenta que no había calculado el potencial de la Sociedad Cooperativa que habían creado los campesinos bajo el manto protector de Claudio, "ni había apercibido mesas e interventores especiales, él, maestro en tales trances, ni había tenido tiempo más que de intentar oponerle sus rondas a la avalancha que habría podido comprar con dinero o con sonrisas". A pesar del resultado electoral, Jarrapellejos explica al ganador que por su falta de experiencia los resultados son inútiles: "Hay que saber las triquiñuelas, en esto como en todo, y las irás aprendiendo. Así, por ejemplo, no se te ha ocurrido levantar del escrutinio actas notariales. ¿De qué puede servir, entonces, que los interventores tuyos, sin yo saberlo, hayan suscrito las actas?... ¡Bah! Hombre, simple, tonto... míralas, soy yo quien las tiene, al fin de la pelea; soy yo quien se las enviará al gobernador, y excuso decirte si me da por romperlas todas y mandar otras... idénticas, con sus sellos y sus firmas". Por todo esto, el cacique expone al candidato vencedor que no le quiere dejar sin representación y que por lo tanto le dejará con un concejal (de los 3 de 5 obtenidos legítimamente), y que de ahora en adelante le enseñará él mismo las "triquiñuelas" para controlar los resultados electorales. "A él, a don Pedro, en cierta época lejana, que mucho sentiría en retornarse, hubo elección que le costó seis mil duros, diez mil duros, quince y veinte mil duros, y más..." Don Pedro le permitirá elegir al concejal que quiera que acceda al cargo, y al terminar le instruye, para mantener las apariencias: "tú, de esto, ni letra. Al revés, le finges a la gente que hemos tenido una agarrada, que te he llamado, molesto por tu triunfo, .para renegar de tu actitud...; y luego, así que unos días las cosas se descubran, sé el primero en sulfurarte contra mí: "¡Bandido! 
¡Bandido! ¡Canalla!”... ¿Eh, sabes?..., lo usual, el repertorio”58. Octavio, a partir de entonces, pasará a trabajar cada vez más estrechamente con Jarrapellejos para mantener el statu quo en el pueblo, y cuando llegue a diputado realizará una transformación similar a la de Marçal Noradell: de "demócrata filósofo materialista" pasará a ser un "aristocrático y devoto organizador" de fiestas religiosas junto al Conde de la Cruz, su tío y principal figura aristocrática del pueblo ${ }^{59}$. Todos estos ejemplos retratan, pues, la fortaleza del sistema y la imposibilidad de acceder a un cargo público sin corrupción electoral, a pesar de que teóricamente se estuviera luchando contra tal fenómeno.

\section{Corrupción urbanística}

El desarrollo y modernización urbanísticos y económicos que empezaba a vivir España durante la Restauración (y que se acentuaría durante la dictadura de Primo de Rivera) comportaron, para los cargos políticos municipales -que accedían a su posición gracias a las tradicionales adulteraciones electorales-, pingües beneficios ${ }^{60}$. Y es que la modernización social y económica de España no aniquiló al caciquismo ni a sus malas praxis, sino que simplemente lo hizo evolucionar ${ }^{61}$. Santiago Rusiñol lo ilustra de la siguiente manera, mostrándonos como al entrar al Ayuntamiento barcelonés, Josepet decidirá hacerse cargo de la gestión del subsuelo ya que "la higiene, que es lo más limpio que tendría que tener un municipio, suele ser lo más sucio, y las cloacas que suelen ser lo más sucio, es el negocio más limpio que pueda tener un concejal de mi categoría y de mi... idiosincrasia. [...] Ya se puede comprender que en aquellos trabajos que hacía a beneficio del pueblo no me había de excluir a mí mismo de la parte del pueblo. Hay un adagio que dice: "Tu haz el bien y no mires a quién". Y me hacía bien a mí, sin mirarme. No hay nada tan abonado a realizar sustracciones pecuniarias como el conreo de las cloacas. El ramo de ensanches, por

\footnotetext{
${ }^{58}$ Felipe TRIGO: Jarrapellejos, pp. 248-251.

${ }^{59}$ Felipe TRIGO: Jarrapellejos, pp. 155 y 391.

${ }^{60}$ Un caso paradigmático es el de Alejandro Lerroux y sus allegados del Partido Radical en el Ayuntamiento de Barcelona. Para un modélico estudio del caso, véase Joan B. CULLA i CLARÀ: El republicanisme lerrouxista a Catalunya (1901-1923) (Barcelona: Curial, 1986).

${ }^{61}$ Un excelente estudio de caso es el realizado por Maria Gemma RUBÍ i CASALS en Els catalans i la política en temps del caciquisme. Manresa, 1875-1923 (Vic: Eumo Editorial, 2006).
} 
ejemplo, como se lo gasta todo en fachadas, es un negocio demasiado a la vista; el de mercados es demasiado peligroso por el envenenamiento general que puede conllevar la parte química de la confección de alimentos; el de consumos todo lo consume en viajes a los fielatos, el de la luz es demasiado luminoso, pero como las cloacas generalmente pasan a oscuras y nadie mira lo que pisa, y el público no es aficionado a visitar estas tinieblas, el concejal que no es quisquilloso y que no es de aquellos que se inquieta si el contratista las arregla a medida, no hay peligro que pierda el rato en esto. [...] Yo, como era el especialista de estas grandes vías subsuelas, y no tenía competidor, a faltarme consciencia, no siendo escrupuloso con el mortero, con el cemento, ni en la construcción, me habría ganado media Barcelona y habría hecho quebrar al municipio, pero lo que se quiere no se rebaja en estos cánones de inmundicia. Cobraba, claro, pero solamente la comisión. Cobraba el porcentaje lícito al que tiene derecho todo hombre de bien que quiere mejorar la cosa urbana, cobraba el sudor del frente y la repugnancia de la nariz, cobraba, en fin, la procura de los bienes comunales que me confiaban, pero era tan poco lo que sustraía de aquellas vías llamémosles fecales, que se necesita la honradez con la que yo ejercía mi cargo para no acabar en el ostracismo. [...] Por poco que cobrase, había tantas tuberías, canalizaciones y cloacas máximas, agujeros en una metrópoli civil tan subsuela como Barcelona, que quieras o no, y resistiéndolo, el dinero te llueve a cántaros. En dos años de administrar, me había llegado más moneda por las vías subterráneas que en quince años por las vías ferroviarias. No tengo que ocultarme de decir que me hice rico. Me hice tan rico que me tuteaba con muchos banqueros, y ya me encontraban gracioso y me hicieron de la junta de un casino intelectual y ya me dibujaban en L'Esquella $^{62}$ calumniándome con el motivo del "Heredero de las cloacas" $y$ recriminándome de un modo injusto la miseria de los mil duros que había hecho a la salud del pueblo, es verdad, pero saneándolo"63. Este ejemplo literario -interesante al retratar una ciudad en plena expansión urbanística como era la Barcelona del momento, que estaba todavía incorporando poblaciones de su alrededor como nuevos

\footnotetext{
${ }^{62}$ L'Esquella de la Torratxa fue un semanario humorístico de carácter republicano nacido en 1872 y publicado, a partir de 1879, periódicamente hasta 1939. Aportando una visión crítica de la sociedad, uno de sus principales centros de atención era la política municipal. Gozó de gran popularidad entre la clase obrera y menestral.

${ }^{63}$ Santiago RUSIÑOL, En Josepet..., pp. 144-146.
} 
barrios- es una buena muestra de la adecuación de las prácticas corruptas a los nuevos escenarios. Son también de sobra conocidos los negocios ilícitos alrededor de la construcción de las redes ferroviarias en esta época en España (una buena lectura sobre las expectativas que conllevaba la expansión del ferrocarril y los caminos extraoficiales que debían recorrerse para su consecución es La febre d'or, de Narcís Oller, 1890) así como la especulación urbanística, que en ciudades como Madrid habían tenido un nivel parecido al barcelonés en el período isabelino. Lamentablemente, estas malas prácticas, entonces todavía en fase embrionaria, perdurarían y tendrían su época de apogeo en el resto del territorio estatal durante la segunda mitad siglo XX y la primera década de siglo XXI.

\section{Conclusiones: una sociedad inmadura}

El panorama de corrupción generalizada que retrata la literatura de la Restauración aquí estudiada no era en absoluto desconocido por los miembros de esta sociedad: la corrupción era denunciada a menudo por los contrincantes políticos de las fuerzas en el poder, ya fuera mediante discursos públicos o en la prensa, pero estas malas prácticas eran toleradas y recibían, como hemos visto en las novelas estudiadas, una escasa contestación. Tal como había literatura de denuncia social, en la España de la Restauración existía un gran número de periódicos, pero este hecho se explica por la necesidad que tenía cada facción política de contar con un órgano portavoz, no porque hubiera una demanda extraordinaria de información ni lectura cabe recordar las altas tasas de analfabetismo registradas por aquél entonces. Además, al ser el control de la información uno de los elementos que más facilita las prácticas corruptas, desde las esferas gubernamentales había distintas fórmulas para incidir sobre el contenido de tal remarcable cantidad de publicaciones. Los periodistas eran sobornados mediante los fondos reservados o de reptiles con los que contaba el ministerio de la Gobernación, o a través de empleos ficticios en la Administración, a las que nunca acudían a trabajar pero de los que cobraban. $Y$ no sólo los periodistas aceptaban sobornos a nivel individual, sino que los periódicos también recibían dinero 
para no publicar una noticia, o hacerlo de forma inocua ${ }^{64}$. Pero estas medidas a veces eran innecesarias: tal como vemos en Jarrapellejos, a veces se publicaban ciertas informaciones que quedaban sin efecto al no haber quien supiera leer el periódico -o porque los caciques encontraran otras fórmulas para desacreditar las afirmaciones de los rotativos. Felipe Trigo lo cuenta así en el caso de La Joya, que tenía un alcalde, Don Fabián, "despreocupado de los formulismos y responsabilidades de su cargo, que con hábiles improvisaciones salía de atolladeros. Antiguo camarada de don Pedro Luis, el juego le arruinó, y don Pedro le hizo alcalde. No había más alcalde que él, desde que empuñó la vara, seis años atrás. Se le vio rápidamente reponerse... Alzar la hipoteca de su casa, comprar tierras, lucir de nuevo a la familia por la carretera del puente en coche... Los fieles amigos achacaban tal prosperidad al simple hecho de haber perdido el vicio a la banca; Gómez, en cambio, portavoz del siempre postergado y pequeño grupo conservador, en su dichoso periódico, no dejaba de largar insidias sobre los trigos del pósito, la venta y los arriendas de la dehesa boyal y los consumos, las contratas de obras del teatro y del mismo Ayuntamiento. Se le dejaba despotricar a Gómez, hombre de puños. Después de todo, maldito si nadie hacía caso de La Voz de La Joya"65.

La España de la Restauración se nos muestra en su obra literaria como un país subdesarrollado, brutal y con una necesidad de un cambio social cada vez más apremiante a medida que el país se fuera urbanizando e industrializando. Es por ello que el tono que impregna las cinco novelas analizadas es de un profundo desasosiego con la sociedad en la que vivían sus autores. Los idealistas que aparecen en sus tramas son personajes llenos de buenas intenciones, pero auténticamente desgraciados: Cidoncha, el profesor socialista del pueblo en Jarrapellejos, es traicionado por su amigo Octavio cuando este sea diputado y acaba marchándose de La Joya después de pasar unos largos meses en prisión acusado sin ninguna prueba de un abominable crimen del que es inocente y por el que los auténticos culpables no pagarán, sino que serán promocionados en la política local y provincial; El catalán de la Mancha fracasará en su intención de transformar Cantalafuente hasta tal punto que su

\footnotetext{
${ }^{64}$ José ÁLVAREZ JUNCO: El Emperador del Paralelo. Lerroux y la demagogia populista (Barcelona: RBA, 2011), pp. 55-56.

${ }^{65}$ Felipe TRIGO: Jarrapellejos, pp. 96-97.
} 
hijo acabará haciéndose célebre en la población al hacerse torero. Cuando éste muera de una cornada, esta especie de Quijote revisitado ${ }^{66}$ que tenía "una percepción de la realidad entelada por un empacho de lecturas mal digeridas que, a inicios del siglo XX, ya no son libros de caballería, sino su equivalente moderno, la Biblioteca Sociológica Internacional que, editada en Barcelona desde 1904, se podía encontrar en cualquier quiosco a peseta el volumen, [y que] había alimentado de ideología a importantes sectores del proletariado barcelonés y se convierte en un elemento recurrente de la novela" ${ }^{67}$, acaba con toda esperanza de emancipación social pacífica y se insinúa al lector, en su huida final, que el único camino que queda es el de la acción directa violenta.

En concordancia con lo que retratan en sus páginas, el recorrido de la denuncia social que se realiza en las cinco novelas estudiadas fue evidentemente limitado, al poder llegar a un porcentaje restringido de la población por las altas tasas de analfabetismo todavía existentes. Pero a pesar del limitado éxito en sus intenciones, las novelas de Trigo, Rusiñol, Bosch de la Trinxeria y López Pinillos tienen un gran valor intrínseco, al ofrecer un testigo privilegiado -por los matices sociales y la profundidad del análisis psicológico aportados- y permitir así a los estudiosos del periodo comprender mejor el clima social en el que se desarrollaba el caciquismo y sobre el que se sostuvo el sistema de la Restauración. Gracias a las novelas aquí estudiadas podemos experimentar la crueldad de la mezcla de indiferencia y opresión en la que vivía entonces el pueblo español, especialmente en los ambientes rurales, y comprender el funcionamiento del Estado a través del complicadísimo entramado de intereses que lo movía. Estos intelectuales no consiguieron cambiar la sociedad en la que vivían, y las reformas gubernamentales emprendidas a partir del Desastre de 1898 (Silvela, Maura) fueron absolutamente insuficientes para regenerar el país. El caciquismo todavía sobrevivió al colapso del sistema de la Restauración y se reinventó a sí mismo para ser parte esencial de la Dictadura de Primo de Rivera (1923-1930). No fue hasta que la sociedad empezó a estar más movilizada políticamente que en las novelas aquí estudiadas que se pudo emprender un intento de cambio efectivo en las

\footnotetext{
${ }^{66}$ Para más información sobre esta visión quijotesca del libro, véase Margarida CASACUBERTA: "Entre el "problema catalán" i la crisi d'Europa: claus per a la recepció d'El català de la Manxa de Santiago Rusiñol”, Els Marges, 104, Tardor 2014, pp. 10-28.

${ }^{67}$ Margarida CASACUBERTA, en el "Epílogo" de El Català de la Manxa, p. 214.
} 
estructuras de poder -a todos los niveles- en España, pero la insurrección de las viejas oligarquías no dejarían que la experiencia de la Segunda República pudiera llegar a buen puerto y que, por tanto, las denuncias de los escritores aquí analizadas tuvieran el eco que ellos esperaban. 